\title{
Endohelminth parasites of the freshwater fish Zoogoneticus purhepechus (Cyprinodontiformes: Goodeidae) from two springs in the Lower Lerma River, Mexico
}

\section{Endohelmintos parásitos del pez dulceacuícola Zoogoneticus purhepechus (Cyprinodontiformes: Goodeidae) en dos manantiales de la cuenca del río Lerma bajo, México}

Andrés Martínez-Aquino, ${ }^{1,3}$, David Iván Hernández-Mena ${ }^{1,3}$, Rodolfo Pérez-Rodríguez ${ }^{1,3}$, Rogelio AguilarAguilar $^{2}$ and Gerardo Pérez-Ponce de León ${ }^{1 \otimes}$

${ }^{1}$ Instituto de Biología, Universidad Nacional Autónoma de México, Apartado postal 70-153, 04510 México, D.F., Mexico.

${ }^{2}$ Departamento de Biología Comparada, Facultad de Ciencias, Universidad Nacional Autónoma de México, Apartado postal 70-399, 04510 México, D.F., Mexico.

${ }^{3}$ Posgrado en Ciencias Biológicas, Universidad Nacional Autónoma de México.

\ppdleon@ibiologia.unam.mx

\begin{abstract}
In order to establish the helminthological record of the viviparous fish species Zoogoneticus purhepechus, 72 individuals were collected from 2 localities, La Luz spring $(n=45)$ and Los Negritos spring $(n=27)$, both in the lower Lerma River, in Michoacán state, Mexico. Twelve helminth taxa were recovered, 5 adults (the digeneans Margotrema bravoae and Phyllodistomum sp., the cestode Bothriocephalus acheilognathi, the nematode Rhabdochona lichtenfelsi and the acanthocephalan Pomphorhynchus cf. bulbocolli), and 7 larvae (the metacercariae of Clinostomum complanatum, the cysticercoid of Cyclophyllidea, the nematodes Rhabdochona sp., Eustrongylides sp., Contracaecum sp. and Spiroxys sp., and the cysthacanth of Polymorphus brevis). Of these, R. lichtenfelsi was the most prevalent and abundant species at La Luz spring with $15.6 \%$ and 0.33 individuals per analyzed host. The remaining species were relatively more rare and infrequent. The helminth parasite community of $Z$. purhepechus at Los Negritos spring was remarkably poor and abundance was very low. The omnivorous feeding habits, the position of the host species in the food web, and the environmental characteristics of each locality are suggested as the main factors determining the helminth parasite communities in this freshwater fish.
\end{abstract}

Key words: Goodeidae, Zoogoneticus purhepechus, helminth parasites, community structure, Mexico.

Resumen. Se examinaron 72 individuos del pez vivíparo Zoogoneticus purhepechus para establecer el registro helmintológico de la especie. Los huéspedes se recolectaron de los manantiales La Luz ( $\mathrm{n}=45)$ y Los Negritos $(\mathrm{n}=27)$, ubicados en la porción baja del río Lerma, en el estado de Michoacán, México. El registro helmintológico consta de 12 especies, incluyendo como adultos los digéneos Margotrema bravoae y Phyllodistomum sp., el céstodo Bothriocephalus acheilognathi, el nemátodo Rhabdochona lichtenfelsi, y el acantocéfalo Pomphorhynchus cf. bulbocolli. Además, como estadios larvarios, se encontraron las metacercarias de Clinostomum complanatum, el cisticercoide de Cyclophyllidea, los nemátodos Rhabdochona sp., Contracaecum sp., Eustrongylides sp. y Spiroxys sp., y el cistacanto de Polymorphus brevis. De éstas, $R$. lichtenfelsi fue la especie más frecuente y abundante en el manantial La Luz, en tanto que las restantes fueron relativamente más raras. La comunidad de helmintos de Z. purhepechus en el manantial Los Negritos fue pobre y poco abundante. Se sugiere que los principales factores que determinan la estructura de la comunidad de helmintos son los hábitos alimentarios omnívoros de los huéspedes, la posición que éstos ocupan en la red trófica y las características ambientales de cada localidad.

Palabras clave: Goodeidae, Zoogoneticus purhepechus, helmintos parásitos, estructura de la comunidad, México.

\section{Introduction}

The genus Zoogoneticus Meek (Cyprinodontiformes: Goodeidae) includes 3 species of livebearing freshwater

Recibido: 18 agosto 2010; aceptado: 31 mayo 2011 fishes, Z. quitzeoensis Bean, Z. tequila Webb and Miller, and the recently described $Z$. purhepechus DomínguezDomínguez, Pérez-Rodríguez and Doadrio. These fish species are restricted to particular river drainages in central Mexico (Domínguez-Domínguez et al., 2008) and are considered as endangered or critically endangered (De la Vega-Salazar et al., 2003; Domínguez-Domínguez 
et al., 2005, 2008). The helminth fauna of livebearing freshwater fishes of the family Goodeidae has been well documented and the depauperate nature of helminth parasite communities in these fishes has been suggested (Astudillo-Ramos and Soto-Galera, 1997; Rojas et al., 1997; Pérez-Ponce de León et al., 2000; MartínezAquino et al., 2004, 2007, 2009; Sánchez-Nava et al., 2004; Martínez-Aquino, 2005; Mejía-Madrid et al., 2005; Romero-Tejeda et al., 2008). However, the only species of Zoogoneticus that has been studied to a certain extent is Z. quitzeoensis and no records of the helminth parasite fauna of the other 2 congeneric species had been established. The main objective of this work is to record the helminth parasite fauna of $Z$. purhepechus collected in 2 sites (Los Negritos and La Luz springs) located in the lower Lerma River Basin, and to describe the helminth community structure and the processes that determine such structure.

\section{Materials and methods}

On July 2009, 72 adult specimens of $Z$. purhepechus were collected using nets in 2 localities, La Luz spring ( $n=$ 45) (19 56'10.4” N, 102 17' 57.8” W; $1616 \mathrm{~m})$ and Los
Negritos spring ( $n=27)\left(20^{\circ} 03^{\prime} 23.1^{\prime \prime} \mathrm{N}, 102^{\circ} 36^{\prime} 38.3^{\prime \prime}\right.$ W; $1539 \mathrm{~m}$ ), in Michoacán state, central Mexico. Hosts were taken alive to the laboratory, pithed and examined individually for intestinal helminths. Other organs (eyes, gall bladder, liver, spleen, swim and urinary bladders) as well as body cavity and musculature, were examined under a stereomicroscope in separate Petri dishes with $0.65 \%$ saline. Digeneans, nematodes and cestodes were fixed with $4 \%$ (steaming) formalin. Acanthocephalans were maintained at $4^{\circ} \mathrm{C}$ for $24 \mathrm{hrs}$. in distilled water, and then fixed in 100\% ethanol. Platyhelminths and acanthocephalans were stained with Meyer's paracarmine. Nematodes were cleared with glycerin for light microscopy and stored in $70 \%$ ethanol. Voucher specimens were deposited in the Colección Nacional de Helmintos (CNHE), Instituto de Biología, Universidad Nacional Autónoma de México, Mexico City (Table 1); when accession number is not provided, specimens were collected for DNA work or scanning electron microscopy. Use of prevalence $(\%$ infected) and abundance (mean number of parasites of a single species in the sample) follows Bush et al. (1997). The non-parametric species richness estimators Chao 1 and Chao 2, were calculated following Colwell and Coddington (1995) and Escalante (2003), and were

Table 1. Endohelminth parasites of Zoogoneticus purhepechus in 2 springs of the Lower Lerma River, Mexico. CNHE= Accession number; $\mathrm{HI}=$ Number of infected hosts; \%= Prevalence; $\mathrm{Ab}=$ Abundance; $\mathrm{SD}=$ Standard deviation; $\mathrm{MI}=\mathrm{Mean}$ intensity

\begin{tabular}{|c|c|c|}
\hline Helminth (Infection site* / CNHE) & $\begin{array}{c}\text { La Luz spring }(n=45) \\
H I / \% / A b \pm S D / M I \pm S D\end{array}$ & $\begin{array}{l}\text { Los Negritos spring }(n=27) \\
H I / \% / A b \pm S D / M I \pm S D\end{array}$ \\
\hline \multicolumn{3}{|l|}{ Adult Digenea } \\
\hline Margotrema bravoae (I) & $1 / 2.2 / 0.02 \pm 0.15 / 1$ & \\
\hline Phyllodistomum sp. (Ub / 7791) & $1 / 2.2 / 0.02 \pm 0.15 / 1$ & \\
\hline \multicolumn{3}{|l|}{ Larval Digenea } \\
\hline Clinostomum complanatum (Bc, M / 7792) & $5 / 11.1 / 0.13 \pm 0.4 / 1.2 \pm 0.45$ & \\
\hline \multicolumn{3}{|l|}{ Adult Cestoda } \\
\hline Bothriocephalus acheilognathi (I, 7793) & & $2 / 7.4 / 0.07 \pm 0.27 / 1$ \\
\hline \multicolumn{3}{|l|}{ Larval Cestoda } \\
\hline Cyclophyllidea gen. sp. (Gb) & & $1 / 3.7 / 0.04 \pm 0.19 / 1$ \\
\hline \multicolumn{3}{|l|}{ Adult Nematoda } \\
\hline Rhabdochona lichtenfelsi (I, 7794) & $7 / 15.6 / 0.33 \pm 0.98 / 2.14 \pm 1.57$ & \\
\hline \multicolumn{3}{|l|}{ Larval Nematoda } \\
\hline Rhabdochona sp. (I, 7108) & & $1 / 3.7 / 0.04 \pm 0.19 / 1$ \\
\hline Contracaecum sp. (L, 7105) & & $1 / 3.7 / 0.07 \pm 0.38 / 2$ \\
\hline Eustrongylides sp. (L, 7106) & & $1 / 3.7 / 0.04 \pm 0.19 / 1$ \\
\hline Spiroxys sp. (M) & $4 / 8.9 / 0.13 \pm 0.5 / 1.5 \pm 1$ & $1 / 3.7 / 0.11 \pm 0.58 / 3$ \\
\hline \multicolumn{3}{|l|}{ Adult Acanthocephala } \\
\hline Pomphorhynchus cf. bulbocolli (I, 7795) & $6 / 13.3 / 0.13 \pm 0.34 / 1$ & \\
\hline \multicolumn{3}{|l|}{ Larval Acanthocephala } \\
\hline Polymorphus brevis (M, 7796) & & $1 / 3.7 / 0.04 \pm 0.19 / 1$ \\
\hline
\end{tabular}

*Infection site: $\mathrm{Bc}=$ Body cavity; $\mathrm{Gb}=$ Gall bladder; $\mathrm{Ub}=$ Urinary bladder; $\mathrm{I}=$ Intestine; $\mathrm{L}=$ Liver; $\mathrm{M}=$ Mesentery 
used to estimate the number of missing species for each component community. Infracommunities include all the helminth species in an individual host, and were described by using the mean number of parasite species per host, the mean number of individual helminths, and the mean value of the Brillouin diversity index. The numerical dominance at the infracommunity level was determined using the Berger-Parker dominance index (Southwood, 1978). Infracommunities were compared qualitatively within the locality using Jaccard similarity index and quantitatively using the Morisita-Horn index, as calculated in Magurran (1988).

\section{Results}

Twelve helminth taxa were recovered from the 2 sampled localities. The helminthological record comprises 3 digenean species: Margotrema bravoae Lamothe-Argumedo, 1970, Phyllodistomum sp., and the metacercariae of Clinostomum complanatum (Rudolphi, 1819); 2 cestodes: the cysticercoid of Cyclophyllidea gen. sp., and Bothriocephalus acheilognathi Yamaguti, 1934; 2 acanthocephalans: the cystacanth of Polymorphus brevis (Van Cleave, 1916) and Pomphorhynchus cf. bulbocolli Van Cleave, 1919; the adult nematode Rhabdochona lichtenfelsi Sánchez-Álvarez, García-Prieto and PérezPonce de León, 1998, and larval forms of Contracaecum sp., Spiroxys sp., Eustrongylides sp., and Rhabdochona sp. La Luz spring. Thirty-four individual helminths were collected from 45 hosts from La Luz spring. These helminths represent 6 species: M. bravoae, Phyllodistomum sp. (adult), C. complanatum (metacercariae), $R$. lichtenfelsi (adult), Spiroxys sp. (larvae), and $P$. cf. bulbocolli (adult). Infection site, number of infected fish, prevalence, abundance, and mean intensity for each helminth taxa are shown in Table 1. The adult nematode $R$. lichtenfels $i$ was the most abundant helminth species, accounting for about $42.8 \%$ of the worms collected in this locality; this nematode reached a prevalence value of $15.6 \%$ and abundance of 0.33 worms per analyzed host. The remaining species were rare, infrequent, and reached very low abundance values (Table 1). Of the 45 analyzed individual hosts, 19 were infected with at least 1 species of helminth in La Luz spring. Only 5 of the 45 hosts harbored 2 or more helminth species. The total number of individuals of all species per host varied from 1 to 7 , with a mean intensity of $0.82 \pm 1.41$. The non-parametric species richness estimators (Chaol and Chao 2) reached a value of 6 . The helminth infracommunities were species-poor. Mean number of species per host was $0.6 \pm 0.8$. The Brillouin index for all infracommunities varied from 0 to 0.599 , with a mean diversity value of $0.099 \pm 0.21$, while the Berger-Parker dominance index values varied from 0.33 to 1 , with a mean of $0.91 \pm 0.2$. The helminth infracommunities displayed a low level of similarity. The corresponding Jaccard index varied from 0 to 1 (mean of $0.18 \pm 0.4$ ) and the Morisita-Horn index varied from 0 to 1 (mean of $0.2 \pm 0.37$ ).

Los Negritos spring. Only 11 individual helminths were collected from Los Negritos spring. The 7 species recovered were $B$. acheilognathi (adult), 1 specimen of Cyclophyllidea (cysticercoid), the larval nematodes Rhabdochona sp., Contracaecum sp., Eustrongylides sp., and Spiroxys sp., and Polymorphus brevis (cystacanth). Infection site, number of infected fish, prevalence, abundance, mean intensity for each helminth species are shown in Table 1. Only $B$. acheilognathi was found in 2 hosts, while the remaining species were even more rare and infrequent (Table 1). The total number of individual helminths of all species per host varied from 1 to 7 , with a mean number of $0.4 \pm 1.4$ individuals per host. The value obtained from the nonparametric species richness estimators (Chao $1=11$ and Chao $2=25$ ), shows that apparently several missing species remaining to be found at the component of community level. The helminth infracommunities were also speciespoor; 2 infracommunities had just 1 species and 1 had a maximum of 4. Mean number of species per host was 0.29 \pm 0.87 . The Brillouin index for all infracommunities varied from 0 to 0.86 , with a mean diversity value of $0.3 \pm 0.41$, while the Berger-Parker dominance index values varied from 0.43 to 1 , with a mean of $0.73 \pm 0.31$. The helminth infracommunities show a low level of similarity. The corresponding Jaccard index varied from 0 to 0.5 (mean of $0.08 \pm 0.2)$ and the Morisita-Horn index varied from 0 to 0.67 (mean of $0.11 \pm 0.27$ ).

The comparison between the helminth parasite fauna of both study sites, exhibits a very low similarity. Table 1 shows that only 1 taxon (Spiroxys sp.) is shared between component communities, resulting in a Jaccard value of 0.17 , and a Morisita-Horn value of 0.23 . However, it is possible that the larval stage of Rhabdochona found in Los Negritos might be conspecific with $R$. lichtenfelsi; although, we were unable to identify this larval satge up to species.

\section{Discussion}

Most of the helminth species found in this study have been previously recorded in diverse freshwater fish species in central and northern Mexico (Mejía-Madrid et al., 2005; Pérez-Ponce de León et al., 2007, 2009, 2010; MartínezAquino and Aguilar-Aguilar, 2008; Romero-Tejeda et al., 2008). Two of these species, the digenean $M$. bravoae and the nematode $R$. lichtenfelsi, are commonly found 
in goodeid fishes, and have been considered as a part of the core parasite fauna for this fish family (Mejía-Madrid et al., 2005; Pérez-Ponce de León and Choudhury, 2005; Martínez-Aquino et al., 2009).

Other helminth species recorded herein as adults were Phyllodistomum sp., P. cf. bulbocolli, and $B$. acheilognathi. The finding of Phyllodistomum sp. in this study represents a new host record for fishes of the family Goodeidae. To date, 6 species of Phyllodistomum have been recorded as a parasite of marine and freshwater fishes in Mexico (Pérez-Ponce de León et al., 2007). In this work, we collected 1 single specimen of this digenean, which hinders the accurate taxonomic determination. Considering the host associations of species of Phyllodistomum in freshwater fishes of North America (Hoffman, 1999), we may speculate that this represents an undescribed species. Further analysis of this worm and those collected from other goodeids in central Mexico (Martínez-Aquino, unpublished data) will allow the proper taxonomic identification of this digenean by using both, morphological and molecular data.

The acanthocephalan $P$. cf. bulbocolli is a parasite of freshwater fishes frequently recorded in North America (Hoffmann, 1999), and it was recently found in Mexico as a parasite of the catostomid Catostomus nebuliferus Garman and the cyprinid Gila conspersa Garman (PérezPonce de León et al., 2009, 2010). The presence of this acanthocephalan in $Z$. purhepechus from La Luz spring represents the third published record for this species in Mexico, and the first record in freshwater fishes of the family Goodeidae. The cestode B. acheilognathi is an introduced species, which currently is widely distributed in freshwater fishes of Mexico (Rojas-Sánchez and García-Prieto, 2008), including several species of goodeids (Peresbarbosa-Rojas et al., 1994; Pérez-Ponce de León et al., 2000; Sánchez-Nava et al., 2004; RomeroTejeda et al., 2008; Pérez-Ponce de León et al., 2009).

The remaining 7 helminth species found in $Z$. purhepechus in both localities were larval stages frequently recorded in the freshwater fish helminth fauna of Mexico and North America. These species were C. complanatum, the cysticercoid of Cyclophyllidea, Contracaecum sp., Eustrongylides sp. and P. brevis, all of them maturing in piscivorous birds, and the nematode Spiroxys sp., which reaches the maturity mainly in freshwater turtles. One single immature specimen of Rhabdochona sp. was found in Los Negritos spring. This nematode most likely belongs to the species $R$. lichtenfelsi, however, absence of reproductive structures prevent its accurate taxonomic determination.

The data we present here suggest that the helminth parasite species composition, and the helminth infracommunity structure in Z. purhepechus is consistent with the pattern that shows a depauperate parasite fauna in goodeid fishes inhabiting freshwaters in the Nearctic part of Mexico such as Alloophorus robustus Bean, Goodea atripinnis Jordan, Allotoca diazi Meek, Chapalichthys encaustus Jordan and Snyder, Characodon audax Smith and Miller, Skiffia lermae Meek, Girardinychthys multiradiatus Meek, Xenotoca variata Bean, Xenotaenia resolanae Turner, and Z. quitzeoensis Bean (AstudilloRamos and Soto-Galera, 1997; Rojas et al., 1997; Pérez-Ponce de León et al., 2000; Martínez-Aquino et al., 2004, 2007, 2009; Sánchez-Nava et al., 2004; MartínezAquino, 2005; Romero-Tejeda et al., 2008). The factors that determine the helminth community structure herein described are concordant with those described in the aforementioned studies (the feeding habits, omnivorous in this case, and the position in the food web of this species of host), i.e., 11 of the 12 helminth species infect their host when it feeds upon some species of crustacean or insect. Likewise, 7 of the 12 helminth species are larval forms that complete their life cycle when the fish is consumed by a definitive host, either a fish-eating bird or a reptile.

On the basis of the values obtained through the species richness estimators used in this study (Chao 1 and Chao 2 ), it seems that we sampled all the helminth fauna in La Luz spring, since the observed and estimated richness value was very similar; however, values obtained for the same richness estimators in Los Negritos spring indicate that various helminth species apparently remain to be found. This result was surprising, since following the idea of Pérez-Ponce de León and Choudhury (2010) that the inventory of the freshwater fish helminth fauna in Mexico is nearing completion, and not many additional species are expected to be found, and particularly in goodeids, since this is a group of hosts that has been extensively studied for helminths in the last years. Thus, this apparently high number of species remaining to be found at Los Negritos spring, could be the result of an artifact derived from very low abundance and mean intensity values for each helminth taxa. Both nonparametric estimators Chao 1 and Chao 2 are sensitive to the presence of rare species (Escalante, 2003), and that is probably the reason of the apparently high number of missing species in that particular locality.

The comparison between the 2 study sites showed that both helminth assemblages had very low numbers of individuals and consequently, remarkable low prevalence and abundance values. However, the helminth community of $Z$. purhepechus at La Luz spring included at least 2 of the species considered specialists for the fish family Goodeidae, the digenean $M$. bravoae and the nematode $R$. 
lichtenfelsi (Pérez-Ponce de León and Choudhury 2005). Likewise, the helminth assemblage of Los Negritos spring is comparatively species-poor, specialist species are lacking, and is conformed only by larval stages and the introduced tapeworm $B$. acheilognathi. This pattern results in very low levels of similarity between the component communities. It is noteworthy the absence of digeneans in Los Negritos spring in conjunction with extremely low abundance values for the helminth species found in that locality. On the other hand, in La Luz, helminth species composition includes at least 3 species of digeneans, even though no tapeworms were found, and abundance values of the helminth parasite fauna are slightly higher than in Los Negritos. We may speculate that this is the result of different environmental conditions of the sampling sites, e.g., primary productivity and associated physicochemical parameters (personal observation), and it is possible that the absence of digeneans in Los Negritos could be the result of the lack of molluscs that are the first intermediate host in their life cycle, however this needs to be determined with the proper sampling in the locality.

Of the 3 recognized species of Zoogoneticus, the helminth parasite fauna has been studied for 2 of them, Z. quitzeoensis, and now, Z. purhepechus. We compared the helminth parasite fauna of $Z$. purhepechus and its putative sister species, Z. quitzeoensis (see DomínguezDomínguez et al., 2008), and some differences were found. The endohelminth fauna of both Zoogoneticus species comprises 16 taxa, including 7 digeneans (4 adults and 3 metacercariae), 2 cestodes ( 1 adult and 1 cysticercoid), 5 nematodes ( 1 adult and 4 larvae), and 2 acanthocephalans (1 adult and 1 larvae) (see MartínezAquino, 2005; Mejía-Madrid et al., 2005; Romero-Tejeda et al., 2008). Only 3 of the 16 taxa (M. bravoae, $B$. acheilognathi, and $R$. lichtenfelsi) are shared between both species. Considering that they are sister species, and even though they do not occur in sympatry, the differences in helminth parasite fauna are a sampling artifact due to the fact that these species have not been studied along their entire distributional range, in the Lower and Middle Lerma River, respectively. We predict that the result of a detailed survey work in other localities along the distribution range for both species, will allow us to find the species that have not yet been documented, increasing as a result the levels of similarity among the parasite fauna.

\section{Acknowledgments}

We thank Lorena Garrido-Olvera for corroborating the identification of the nematodes. AMA and RPR were supported by a Research Doctoral Fellowships from the Consejo Nacional de Ciencia y Tecnología (CONACyT), Mexico. D.I.H.M. thanks CONACyT for scholarship to accomplish his MSc degree. The study was funded by grants from the Consejo Nacional de Ciencia y Tecnología (CONACyT, No. 83043), and the Programa de Apoyo a Proyectos de Investigación e Innovación Tecnológica (PAPIIT-UNAM IN 202111) to G.P.P.L.

\section{Literature cited}

Astudillo-Ramos, L. and E. Soto-Galera. 1997. Estudio helmintológico de Chirostoma humboldtianum y Girardinichthys multiradiatus capturados en el Lerma. Zoología Informa 35:53-59.

Bush, A. O., K. D. Lafferty, J. M. Lotz and A. W. Shostak. 1997. Parasitology meets ecology on its own terms: Margolis et al. revisited. Journal of Parasitology 65:667-669.

Colwell, R. K. and J. A. Coddington. 1995. Estimating terrestrial biodiversity through extrapolation. In Biodiversity: measurement and estimation, D. L. Hawksworth, (ed.). Chapman and Hall, London. p. 101-118.

De la Vega-Salazar, M. Y., E. Ávila-Luna and C. Macías-García. 2003. Ecological evaluation of local extinction: the case of two genera of endemic Mexican fish, Zoogoneticus and Skiffia. Biodiversity and Conservation 12:2043-2056.

Domínguez-Domínguez, O., N. Mercado-Silva, J. Lyons and H. J. Grier. 2005. The viviparous goodeid fishes. In Viviparous fishes, M. C. Uribe and H. J. Grier (eds.). New Life Publications, Homestead, Florida. p. 525-569.

Domínguez-Domínguez, O., R. Pérez-Rodríguez and I. Doadrio. 2008. Morphological and genetic comparative analyses of populations of Zoogoneticus quitzeoensis (Cyprinodontiformes: Goodeidae) from Central Mexico, with description of a new species. Revista Mexicana de Biodiversidad 79:373-383.

Escalante, T. 2003. ¿Cuántas especies hay?: los estimadores no paramétricos de Chao. Elementos 52:53-56.

Hoffman, G. L. 1999. Parasites of North American freshwater fishes. $2^{\text {nd }}$ edition. Cornell University Press, California. 539 p.

Magurran, A. 1988. Ecological diversity and its measurement. Croom Helm, London. 179 p.

Martínez-Aquino, A. 2005. Biogeografía de helmintos parásitos de peces de la familia Goodeidae (Pisces: Cyprinodontiformes) del centro de México. Tesis, Facultad de Ciencias, Universidad Nacional Autónoma de México, México, D.F. 129 p.

Martínez-Aquino, A. and R. Aguilar-Aguilar. 2008. Helminth parasites of the pupfish Cyprinodon meeki (Pisces: Cyprinodontiformes), an endemic freshwater fish from North-Central Mexico. Helminthologia 45:48-51. 
Martínez-Aquino, A., R. Aguilar-Aguilar, R. Pérez-Rodríguez and G. Pérez-Ponce de León. 2009. Helminth parasites of Xenotaenia resolanae (Osteichthyes: Cyprinodontiformes: Goodeidae) from the Cuzalapa hydrological system, Jalisco, Mexico. Journal of Parasitology 95:1221-1223.

Martínez-Aquino, A., G. Salgado-Maldonado, R. AguilarAguilar, G. Cabañas-Carranza and C. Mendoza-Palmero. 2007. Helminth parasite communities of Characodon audax and $C$. lateralis (Pisces: Goodeidae), endemic freshwater fishes from Durango, Mexico. The Southwestern Naturalist 52:125-130.

Martínez-Aquino, A., G. Salgado-Maldonado, R. AguilarAguilar, G. Cabañas-Carranza and M. P. Ortega-Olivares. 2004. Helminth parasites of Chapalichthys encaustus (Pisces: Goodeidae), an endemic freshwater fish from Lake Chapala, Jalisco, Mexico. Journal of Parasitology 90:889-890.

Mejía-Madrid, H., O. Domínguez-Domínguez and G. PérezPonce de León. 2005. Adult endohelminth parasites of Goodeinae (Cyprinodontiformes: Goodeidae) from Mexico with biogeographical considerations. Comparative Parasitology 72:200-211.

Peresbarbosa-Rojas, E., G. Pérez-Ponce de León and L. GarcíaPrieto. 1994. Helmintos parásitos de tres especies de peces (Goodeidae) del Lago de Pátzcuaro, Michoacán. Anales del Instituto de Biología, Universidad Nacional Autónoma de México, Serie Zoología 65:201-204.

Pérez-Ponce de León, G. and A. Choudhury. 2005. Biogeography of helminth parasites of freshwater fishes in Mexico: the search for patterns and processes. Journal of Biogeography 32:645-659.

Pérez-Ponce de León, G. and A. Choudhury. 2010. Parasite inventories and DNA-based taxonomy: Lessons from helminths of freshwater fishes in a megadiverse country. Journal of Parasitology 96:236-244.

Pérez-Ponce de León, G., L. García-Prieto, V. León-Règagnon and A. Choudhury. 2000. Helminth communities of native and introduced fishes in Lake Pátzcuaro, Michoacán, Mexico. Journal of Fish Biology 57:303-325.

Pérez-Ponce de León, G., L. García-Prieto and B. MendozaGarfias. 2007. Trematode parasites (Platyhelminthes) of wildlife vertebrates in Mexico. Zootaxa 1534:1-247.

Pérez-Ponce de León, G., R. Rosas-Valdez, R. Aguilar-Aguilar, B. Mendoza-Garfias, C. Mendoza-Palmero, L. García-Prieto, A. Rojas-Sánchez, R. Briosio-Aguilar, R. Pérez-Rodríguez and O. Domínguez-Domínguez. 2010. Helminth parasites of freshwater fishes, Nazas River basin, northern Mexico. CheckList 6:26-35.

Pérez-Ponce de León, G., R. Rosas-Valdez, B. Mendoza-Garfias, R. Aguilar-Aguilar, J. Falcón-Ordaz, L. Garrido-Olvera and R. Pérez-Rodríguez. 2009. Survey of endohelminth parasites of freshwater fishes in the upper Mezquital River basin, Durango state, Mexico. Zootaxa 2164:1-20.

Rojas, E., G. Pérez-Ponce de León and L. García-Prieto. 1997. Helminth community structure of some freshwater fishes from Patzcuaro, Michoacan, Mexico. Tropical Ecology 38:129-131.

Rojas-Sánchez, A. and L. García-Prieto. 2008. Distribución actual del céstodo Bothriocephalus acheilognathi en México. Memorias XXV Simposio sobre Fauna Silvestre, Facultad de Medicina y Zootecnia, Universidad Nacional Autónoma de México, Mexico. p. 89-93.

Romero-Tejeda, M. L., L. García-Prieto, L. Garrido-Olvera and G. Pérez-Ponce de León. 2008. Estimation of the endohelminth parasite species richness in freshwater fishes from La Mintzita reservoir, Michoacán, Mexico. Journal of Parasitology 94:288-292.

Sánchez-Nava, P., G. Salgado-Maldonado, E. Soto-Galera and B. Jaimes-Cruz. 2004. Helminth parasites of Girardinichthys multiradiatus (Pisces: Goodeidae) in the upper Lerma River sub-basin, Mexico. Parasitology Research 93:396-402.

Southwood, T. R. 1978. Ecological methods, 2nd ed. Chapman \& Hall, London. 524 p. 